\title{
SUBSISTENCE LIVING AND GLOBAL CLIMATE CHANGE: IMPLICATIONS OF BIOCHARCOAL PRODUCTION FOR FARMERS IN RURAL AREAS OF NIGERIA
}

*Ajadi, K. O., Alabi, F. M. and Adebisi, J.A.

DOI: http://dx.doi.org/10.4314/ejesm.v5i1.8

Received $22^{\text {nd }}$ December; accepted 10th January 2012

\begin{abstract}
The study examines socio-economic implications of charcoal production for farmers of rural communities in Nigeria using selected communities in Ifedapo Region of Oyo State. From a total of 67 charcoal producing rural communities identified in the region, 16(30\%) was proportionally selected using three sampling techniques (stratified, purposive and simple random sampling). A total of 32 colliers and 8 middle traders (wholesalers) were selected as respondents to form the representative sample of the studied population. A-25 item questionnaire was the instrument used for the study. The survey reveals that charcoal producers are mainly male, married adult farmers with little or no education. The charcoal enterprise has been on part-time basis, undertaken as a coping strategy, and the forest is depleting due to uncontrolled and indiscriminate exploitation of mature and nearly-mature trees. Its production would not stop because available alternatives are limited and expensive. Consequently, creating short-term employment during off-season period for farmers, subsidising agricultural inputs, an appropriate policy that delivers gas and kerosene to the end-users for domestic use at affordable price, community participation in forest management, researches into the use of wind and solar energies, law against cutting down of trees without replacement and implementation of the components of the national planning programmes, which pertain to afforestation, discourage farmers from charcoal production.
\end{abstract}

Keywords: Fuelwood, Deforestation, Biocharcoal, Subsistence Living

\section{Introduction}

Charcoal export started in Nigeria in 1904 (Light and Sound, 2009). In 2000, 67,767,000 cubic metres (2.4 billion cubic feet) of round wood were produced, $85 \%$ for fuel. In the same year, Nigeria's consumption of fuel wood and charcoal was the third highest in Africa (Olori, 2009). Of the country's population of over 144 million, about $70 \%$ live in rural areas and are directly or indirectly dependent on forest resources- especially wood - to meet both domestic and economic energy needs. This activity is leading to destruction of forest cover, a situation aggravated by illegal commercial logging (Olori 2009). FAO (2005) indicates that between 1990 and 2005, Nigeria lost 35.7\% of its forest cover and only $12.2 \%$ of the country's land is currently forested while 350,000 hectares of land in the country are lost to desertification annually.

Problems posed by the production of charcoal are numerous. Adeniyi (1995) and Wikipedia Encyclopedia (2005) noted that the problems in

Department of Urban and Regional Planning,

The Polytechnic Ibadan, Nigeria

*Corresponding author email:ajadikoo2004@yahoo.com
Nigeria include environmental pollution from smoke, deforestation which causes erosion hazard and exposes the soil to direct sunshine, thereby reducing the fertility of the soil and the health problems to the producers and the entire community as a whole.

Charcoal production is associated with felling of both mature and nearly-mature trees in the study area. The study, therefore, aims at examining the charcoal production, method and the reason(s) for the production, with a view to identify the social and economic implications of the activity to the colliers (farmers) and problems posed by the commercial production of charcoal to the environment. Mitchell, (2009) noted that deforestation is a global emergency, the importance of which the business world must wake up to, especially, to mitigate the effect of global climatic change. It also suggests solutions that could improve production and mitigate the adverse effects of charcoal production, and provoke policy towards deforestation in Nigeria. 


\section{Study Area}

Ifedapo region in Oyo State of Nigeria is used as a case study. The region provides a representative insight into the socio-economic conditions of farmers as regards to the production of charcoal in Nigeria. There are 36 states in Nigeria of which Oyo State is one. Oyo state has five administrative zones, namely Ibadan, Ibarapa, Oyo, Ogbomoso, and Oke-Ogun. Oke-Ogun comprises four regions: Iseyin, Irepodun, Kajola and Ifedapo (Ajadi, 2004). Ifedapo region is located in the northern part (savannah belt) of Oyo State, Nigeria. It comprises three local government areas out of the 33 local government areas in Oyo State: Saki west (Saki town), Saki east (Ago-Amodu) and ATISBO (Tede). Saki town, which is the major urban town in the region, is about 184 and 320 kilometres from Ibadan and Lagos respectively, and the major occupation of the people is farming.

The region is within the savannah belt of Nigeria and is located on Latitude $8.5^{\circ} \mathrm{N}$ and Longitude $3.5^{0} \mathrm{E}$. In the rainy season, there are broad, green leaves trees characterised by fireresistant, thick bark and deep tap root. Such trees include viteloria paracloxum (Emin) trees, Khaya ivorensis (Ogano), Triplochiton scleroxylon (Arere), Anogeissus leiocarpus (Ayin), Burkea africana (Asapa), Distemonanthus benthamianus (Ayan), Perkia bigolobosa (Igba), Terminalia avicenniocles (Idi), Gmelina arborea (Igi Isana), Milicia excelsa (Iroko), Tectona grandis (Gedu) and so on. The study area experiences tropical climatic condition, which include wet and dry seasons which occur from April to October and February to April respectively. Harmattan, which is a cool dry wind from the Sahara, occurs between November and February. The temperature ranges from $20^{\circ} \mathrm{C}$ to $36^{\circ} \mathrm{C}$ and the average relative humidity is $10 \%$ but can be up to $85 \%$ in the night and low as $59 \%$ in the afternoon. It has an annual rainfall of 102mm (Udo, 1987; Popoola, 2009).

\section{Methodology}

The methodology of this study involves the use of library books, journals, magazines, newspapers, internet sources and primary sources. The population of the study comprises all the villagers involved in charcoal production and sale in Saki West, Saki East and ATISBO Local Government areas. Three sampling techniques (purposive, stratified and simple random sampling) were adopted for selecting the sample of the study population. The whole region was divided (stratified) into three sub-study areas according to local government areas, which the region is currently made of. A total number of 53 charcoal producing communities were identified from the three local governments through a purposive interview of 8 selected wholesalers in Saki town, Ago-Are, Agunrege and Oje-Owode charcoal depots. These are Saki West (13) Saki East (23) and ATISBO (17) from which 16 (30\%) charcoalproducing communities were proportionally selected. Only $16(30 \%)$ communities were selected through simple random sampling technique (lucky dip/blind dip method). A total of 32 respondents (2 colliers per community) were selected to form the representative sample of the study population. The main instrument of this study was a 25-item questionnaire. The data collected from primary source was coded and further analyse by descriptive technique in the form of frequency tables. Moreover, 8 major middle traders (wholesalers) were purposively selected for interview orally to solicit for cost of transportation, problems faced and suggestions towards improving the business of charcoal.

Table 1 Number of identified charcoal communities, charcoal communities selected and the number of respondents' selected

\begin{tabular}{|l|l|l|l|l|}
\hline Local Government & $\begin{array}{l}\text { Charcoal } \\
\text { Communities }\end{array}$ & $\begin{array}{l}\text { Number Charcoal } \\
\text { Communities Selected }\end{array}$ & $\begin{array}{l}\text { Respondents } \\
\text { Sampled }\end{array}$ & \% \\
\hline Saki West & 13 & 4 & 8 & 25.00 \\
\hline Saki East & 23 & 7 & 14 & 43.00 \\
\hline ATISBO & 17 & 5 & 10 & 31.00 \\
\hline Total & $\mathbf{5 3}$ & $\mathbf{1 6}$ & $\mathbf{3 2}$ & $\mathbf{1 0 0 . 0 0}$ \\
\hline
\end{tabular}

Source Field Survey, January, 2008 -December 2009. 
Results and Discussion

Charcoal Production Operation in the Study Area

Charcoal production in the study area, as observed during the study, generally consists of pilling billets of wood on their end so as to form a conical pile, openings being left at the bottom to admit air, with a central shaft to serve as fuel. The whole pile is covered with turf or moistened clay. The firing is begun at the bottom of the flue and gradually spreads outwards and upwards. The collier and his assistants kept a wary eye on the steaming, smoking pile to guard against blowouts that might lead to flaming of the pile. Colliers often had to cut or dig holes at various spots on the pile to ensure proper air flow. During the first twenty-four hours, the collier would have to occasionally "jump the pile". This dangerous task requires the collier to climb on top of the smoking mass, so as to compact the pile and assure an even burn. As the burn continues and the smoke and steam subside, the raking out begins.

Table 2 Socio-economic Characteristics of the Respondents

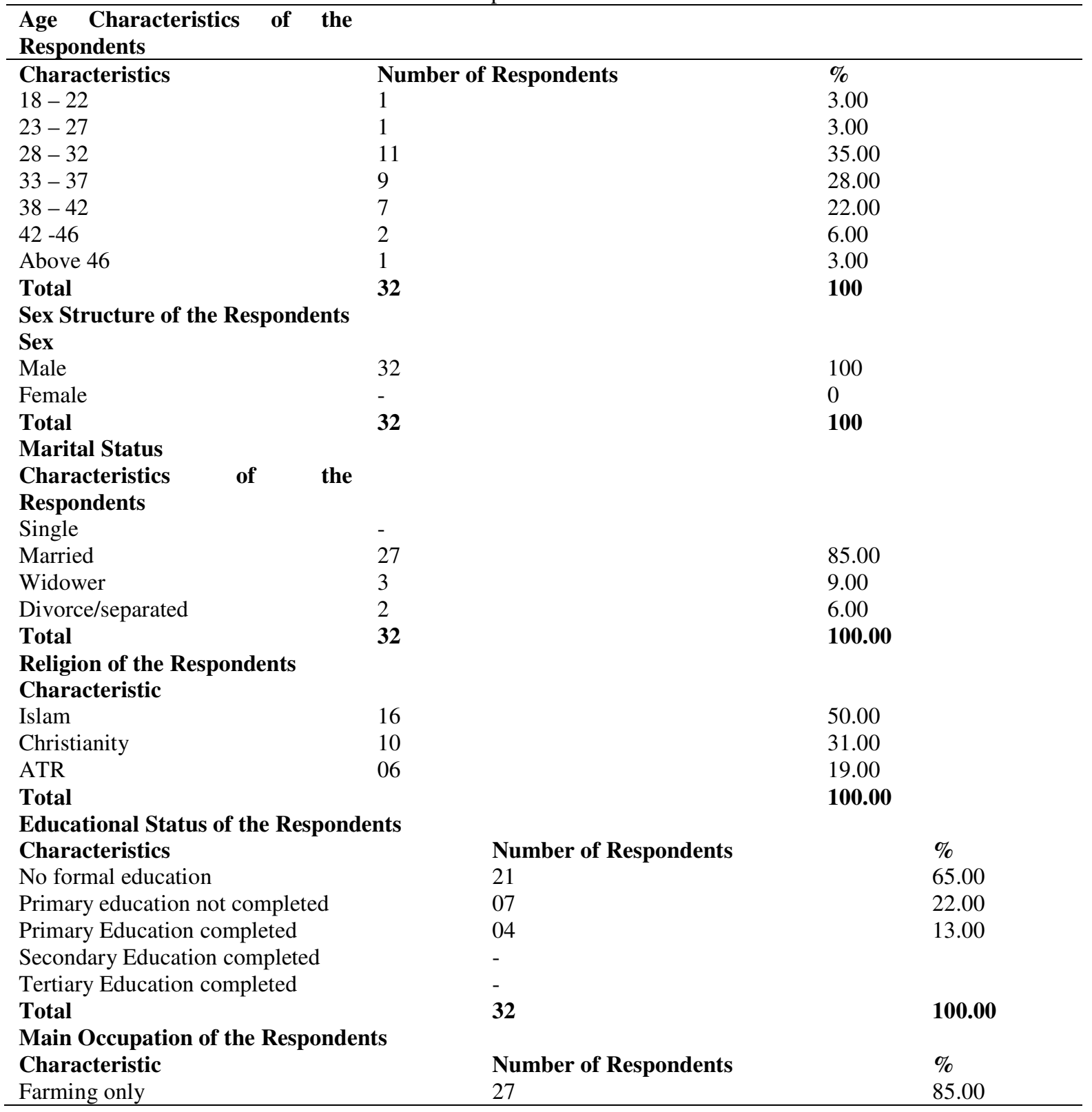




\begin{tabular}{lll}
\hline Farming \& Trading & 03 & 9.00 \\
Farming \& Hunting & 02 & 6.00 \\
Others & - & - \\
Total & $\mathbf{3 2}$ & $\mathbf{1 0 0 . 0 0}$ \\
Family Size of the Respondents & Number of Respondents & $\mathbf{\%}$ \\
Characteristic & 1 & 3.00 \\
$0-5$ & 17 & 53.00 \\
$6-10$ & 12 & 38.00 \\
$11-16$ & 02 & 6.00 \\
Above 16 & $\mathbf{3 2}$ & $\mathbf{1 0 0 . 0 0}$ \\
Total & & $\mathbf{\%}$ \\
Nationality of the Respondents & Number of Respondents & 41.00 \\
Characteristics & $\mathbf{1 3}$ & 59.00 \\
Nigerians & 19 & $\mathbf{1 0 0 . 0 0}$ \\
Others & $\mathbf{3 2}$ & \\
Total & & $\mathbf{\%}$ \\
Region within the Country (Nigeria) of the & & 23.00 \\
Respondents & Number of Respondents & 77.00 \\
Characteristics & 3 & $\mathbf{1 0 0 . 0 0}$ \\
Ifedapo & 10 & $\mathbf{1 3}$ \\
Outside Ifedapo Region \\
Total
\end{tabular}

Source: Field Survey, January2008-December 2009.

Result in Table 2 shows that a higher percentage of the colliers are Non-Nigerians and most of the colliers from Nigeria came outside the region (Ifedapo).

The price of a bag of charcoal is not uniform among the producing communities, but fluctuates seasonally (Table 3 ). The price could be as low as between N100.00 and N150.00 and between $\mathrm{N} 250.00$ and N300.00 in the dry and rainy seasons respectively. But the prices in the urban areas are relatively stable within a season. The rise in price is due to trucked transportation into urban centres from even-greater distances (Table 4). The result in table 5 indicates the comparative average profit of a bag $(15 \mathrm{~kg})$ of charcoal in the producing communities and the urban cities. The table shows that higher profits are made in urban areas and this encourages the involvement in the sale of charcoal by the urban dwellers. The result in table 6 indicates that it is cheaper to use charcoal for cooking. The increase in the profit level encouraged hoarding during the dry season. The cheapest fuel used for domestic purpose is charcoal (Table 7).

Table 3 Seasonal Average Selling Price of a Bag of Charcoal (15kg) in the Producing Communities (Villages)

\begin{tabular}{|c|c|c|}
\hline $\begin{array}{l}\text { Characteristics } \\
\text { Naira) }\end{array}$ & $\begin{array}{lr}\text { Number } & \text { of } \\
\text { Communities } & \text { (Dry } \\
\text { Season-November) } & \\
\end{array}$ & Number of Communities (Wet Season- July) \\
\hline N100 - N150 & 1 & - \\
\hline N151 - N200 & 13 & - \\
\hline $\mathrm{N} 201-\mathrm{N} 250$ & 16 & - \\
\hline $\mathrm{N} 251-\mathrm{N} 300$ & 2 & 26 \\
\hline N301 - N350 & - & 6 \\
\hline Total & 32 & 32 \\
\hline
\end{tabular}

Source: Field Survey, January 2008 - December 2009. 
Table 4 Seasonal Average Price of a Bag (15g) of Charcoal in the Producing Communities and in the Urban Areas

\begin{tabular}{|l|l|l|l|l|}
\hline Settlements & $\begin{array}{l}\text { Average prices/15kg } \\
\text { in naira]in the dry } \\
\text { season (November) }\end{array}$ & $\begin{array}{l}\text { Average } \\
\text { prices/15kg (in } \\
\text { naira) in the } \\
\text { rainy season } \\
\text { (July) }\end{array}$ & Differences & $\begin{array}{l}\text { Percentage } \\
\text { increase }\end{array}$ \\
\hline $\begin{array}{l}\text { Producing } \\
\text { Communities }\end{array}$ & $\mathrm{N} 250.00$ & $\mathrm{~N} 100.00$ & 66 \\
\hline Saki & $\mathrm{N} 300.00$ & $\mathrm{~N} 600.00$ & $\mathrm{~N} 300.00$ & 100 \\
\hline Ogbomosho/Oyo & $\mathrm{N} 500.00$ & $\mathrm{~N} 900.00$ & $\mathrm{~N} 400.00$ & 80 \\
\hline Ibadan & $\mathrm{N} 600.00$ & $\mathrm{~N} 1500.00$ & $\mathrm{~N} 900.00$ & 150 \\
\hline Lagos & $\mathrm{N} 1200.00$ & $\mathrm{~N} 3000.00$ & $\mathrm{~N} 1800.00$ & 150 \\
\hline
\end{tabular}

Source: Field Survey, January2008-December2009 ( $\$ 1$ to $=\mathrm{N}=156.00)$

Table 5 Average Profit on a Bag $(15 \mathrm{~kg})$ of Charcoal in the Producing Communities and in the Urban Areas (Rainy Season -July)

\begin{tabular}{|l|l|l|l|}
\hline Settlements & $\begin{array}{l}\text { Average } \\
\text { prices/15kg } \\
\text { [naira] rainy } \\
\text { season [July] }\end{array}$ & Differences & $\begin{array}{l}\text { Percentage } \\
\text { increase (\%) }\end{array}$ \\
\hline $\begin{array}{l}\text { Producing } \\
\text { Communities }\end{array}$ & N250.00 & & \\
\hline Saki & N600.00 & N350.00 & 140 \\
\hline Ogbomosho/Oyo & N900.00 & N650.00 & 260 \\
\hline Ibadan & N1500.00 & N1250.00 & 500 \\
\hline Lagos & N3000.00 & N2750.00 & 1100 \\
\hline
\end{tabular}

Source: Field Survey, January2008-December 2009. ( $\$ 1$ to $=\mathrm{N}=156.00)$

Table 6 Average Price of Alternative Source of Domestic Fuel (Kerosene and Gas)

\begin{tabular}{|l|l|l|}
\hline Urban Centres & $\begin{array}{l}\text { Average price of kerosene } \\
\text { /litre }\end{array}$ & $\begin{array}{l}\text { Average price of domestic gas } \\
\text { /12.5kg }\end{array}$ \\
\hline Saki & $\mathrm{N} 140.00$ & $\mathrm{~N} 3800.00$ \\
\hline Ogbomosho/Oyo & $\mathrm{N} 140.00$ & $\mathrm{~N} 3800.00$ \\
\hline Ibadan & $\mathrm{N} 130.00$ & $\mathrm{~N} 3500.00$ \\
\hline Lagos & $\mathrm{N} 140.00$ & $\mathrm{~N} 3500.00$ \\
\hline
\end{tabular}

Source: Field Survey, January2008- December 2009( $\$ 1$ to $=\mathrm{N}=156.00)$

Table 7 Average Usage of Sources of Domestic Fuel [Kerosene, Gas and Charcoal) in Saki, Oyo, Ogbomoso, Ibadan and Lagos

\begin{tabular}{|l|l|l|}
\hline Domestic Fuel & $\begin{array}{l}\text { Average Usage For a } \\
\text { Family of Five /Month }\end{array}$ & Average Amount per Month (Naira) \\
\hline Kerosene & 35 litres & $\mathrm{N} 4900.00$ \\
\hline Gas & $12.5 \mathrm{~kg}$ & $\mathrm{~N} 3500.00$ \\
\hline Charcoal & $1 \mathrm{bag}$ & $\mathrm{N} 1500.00$ \\
\hline
\end{tabular}

Source: Field Survey, January 2008-December 2009 ( $\$ 1$ to $=\mathrm{N}=156.00)$ 
Table 8 The Main Determinants of the Price of Charcoal

\begin{tabular}{|l|l|l|l|}
\hline Characteristics(Determinants) & $\begin{array}{l}\text { Number of } \\
\text { respondents(Collier) }\end{array}$ & $\begin{array}{l}\text { Total Number of } \\
\text { 'Yes' Respondents }\end{array}$ & $\begin{array}{l}\text { \% of 'Yes' } \\
\text { Respondents }\end{array}$ \\
\hline Demand & 32 & 32 & 100 \\
\hline Quality of the product & 32 & 32 & 100 \\
\hline Availability of wood & 32 & 32 & 100 \\
\hline Cost of transportation/Distance & 32 & 32 & 100 \\
\hline Supply & 32 & 32 & 100 \\
\hline Total & $\mathbf{1 6 0}$ & $\mathbf{1 6 0}$ & \\
\hline
\end{tabular}

Source: Field Survey, January2008-December 2009.

The finding shows that a producer produces an average of 11 - 15 bags of charcoal per week especially in the dry season. It could be inferred from Tables 4 and 8 that there is great demand for charcoal in urban areas. The reasons attributed to the fact is that charcoal burns much hotter than cut wood, lighter to transport and available alternative is limited and expensive both in the rural and urban communities. It was also observed that charcoal last in storage without degradation many years longer than fuel wood and therefore the preference for charcoal (Table 9).

The results show that the charcoal production is often a seasonal activity and the rainy season may

close down operations or the labour force may traditionally be employed at certain times in harvesting or planting operations in agriculture (Tables 2, 10 and 11). This shows that charcoal production is not being undertaken by the people because of its profit and viability, but rather as coping strategy to supplement the high price of farming input of the subsequent season. It also serves as the stabilising tool for partial farming offseason unemployment. It could also be inferred from the result in Table 12, as it indicates that charcoal production is a low profit yielding enterprise to the collier as compared to middle traders (wholesalers) as revealed by the oral interview and therefore it could not be said to be a highly profitable enterprise.

Table 9 Reasons for High Demand of Charcoal

\begin{tabular}{|l|l|l|l|}
\hline Reason & No of respondents & $\begin{array}{l}\text { Total no of 'yes' } \\
\text { Respondents }\end{array}$ & $\begin{array}{l}\text { Percentage of 'Yes' } \\
\text { Respondents }\end{array}$ \\
\hline Price of charcoal & 32 & 32 & 100 \\
\hline Burns much Hotter & 32 & 32 & 100 \\
\hline Lighter to carry & 32 & 32 & 100 \\
\hline Last in storage & 32 & 32 & 100 \\
\hline Availability & 32 & 32 & 100 \\
\hline
\end{tabular}

Source: Field Survey, January 2008-December 2009.

Table 10 Seasonal Participation in the Production of Charcoal by the Respondents

\begin{tabular}{|l|l|l|}
\hline Season & No of Respondents & $\mathbf{\%}$ \\
\hline Wet & 01 & 3.00 \\
\hline Dry & 30 & 94.00 \\
\hline Both (Wet and Dry) & 01 & 3.00 \\
\hline Total & $\mathbf{3 2}$ & $\mathbf{1 0 0 . 0 0}$ \\
\hline
\end{tabular}

Source: Field Survey, January2008-December 2009

Table 11 Terms of Production by the Respondents

\begin{tabular}{|l|l|l|}
\hline Term & No & \% \\
\hline Full time & 01 & 3.00 \\
\hline Part time & 31 & 97.00 \\
\hline Total & $\mathbf{3 2}$ & $\mathbf{1 0 0 . 0 0}$ \\
\hline
\end{tabular}

Source: Field Survey, January2008-December 2009. 
Table 12 Problems of Charcoal Production

\begin{tabular}{|l|l|l|l|l|l|l|}
\hline Problems & $\begin{array}{l}\text { Strongly } \\
\text { agreed }\end{array}$ & Agreed & Indifferent & Not Agreed & $\begin{array}{l}\text { Strongly } \\
\text { not agreed }\end{array}$ & $\begin{array}{l}\text { Total No. of } \\
\text { Respondents }\end{array}$ \\
\hline Labour intensive & 29 & 3 & - & - & - & 32 \\
\hline Capital intensive & & & - & 11 & 21 & 32 \\
\hline Scarcity of Hardwood & 17 & 15 & - & - & - & 32 \\
\hline Land tenure & 00 & 03 & 09 & - & 20 & 32 \\
\hline Bon-fire lingering & - & - & - & - & 32 & 32 \\
\hline Distance of the mound & 19 & 13 & - & - & - & 32 \\
\hline Law enforcing agents & - & - & - & 3 & 29 & 32 \\
\hline Low profit margin & 32 & - & - & - & - & 32 \\
\hline
\end{tabular}

Source: Field Survey, January2008-December 2009.

Result in Table 12 further shows that other problems include the scarcity of mature hardwood which calls for a greater distance-travel and incursion into the government forest reserves to produce the charcoal. This shows that deforestation or consumption of mature hardwood exceeds regeneration if any (Table 13). This means that the forest is gradually shrinking due to uncontrolled (by the government officials) and indiscriminate exploitation or felling of mature or nearly mature trees of the privately-owned forest for charcoal and fuelwood (Table 14).
The study revealed that the majority of the colliers did not obey the law owing to lack of will and discipline to observe and implement laws by compromised local government officials, forest guard and so on. The study also revealed that there was no record of production in terms of the number of trees cut, the weight of trees used to produce certain number of bags of charcoal, and daily, monthly and annual production and sales of charcoal. This made it impossible for the authors to know whether there is relationship between variables, the direction of the relationship or/and the strength of the correlation.

Table 13 Regeneration of the Forest by the Collier

\begin{tabular}{|l|l|l|}
\hline Responses & No of Respondents & $\mathbf{\%}$ \\
\hline Yes & 0 & 0 \\
\hline No & 32 & 100 \\
\hline Total & $\mathbf{3 2}$ & $\mathbf{1 0 0 . 0 0}$ \\
\hline
\end{tabular}

Source: Field Survey, January-December 2009.

Table 14 Regulation of Private Forest Tree Felling by the Local Government Officials

\begin{tabular}{|l|l|l|}
\hline Responses & No of Respondents & $\mathbf{\%}$ \\
\hline Yes & 0 & 0 \\
\hline No & 32 & 100 \\
\hline Total & $\mathbf{3 2}$ & $\mathbf{1 0 0 . 0 0}$ \\
\hline
\end{tabular}

Source: Field Survey, January2008-December 2009.

Menne and Bertollini (2000) describe five major global environmental problems, which points to the potential impact on future generations. These are climate change, ozone layer depletion, dissertation, deforestation and child mortality, loss of biodiversity and, charcoal production and greenhouse emission source. From nearly 470 million tons of wood consumed in 2000 in homes in sub-Saharan Africa in the form of firewood and charcoal, more wood per capita than any other region in the world, Hao and Liu (1994) estimate that of these fires, $10 \%$ is 
attributed to deforestation and emissions from traditional cooking in Africa are significant enough to influence the tropical and subtropical atmosphere, they concluded. Marufu (1999) concludes by stressing that with the rapidly growing urban-poor populations in sub-Saharan African countries (urbanisation rates of $4.8 \%$ ) the demand for charcoal is also growing with similar implications for local and regional air pollution.

\section{Conclusion and Recommendations}

From the foregoing, it could be inferred from the study that one of the environmental problems in Nigeria in particular and Africa in general is the way our forests are fast-disappearing due to uncontrolled and indiscriminate felling of trees for use as fuel or charcoal both of which are the means of cooking for most families. It is therefore important to say that if there is any justifiable reason for the removal of subsidies from all other petroleum products, government subsidies on domestic gas and kerosene should be maintained in order to save our forests from further depletion. There should be an appropriate policy that delivers gas and kerosene to end-users for domestic use at affordable prices.

There should not be a great sense of urgency to stop the production of charcoal since the availability of alternative to charcoal is not only limited but also expensive to get to all nooks and crannies of the country. What is required now is a measure to control or regulate the cutting of trees for fuel. This could be done through monitoring the formation of registered associations, for example, Collier Association like the Miners' Association, which would be saddled with taking records of felled trees and sales among other functions. This would go a long way in enhancing reforestation enlightenment.

There should be a development and promotion of other energy sources such as solar and wind energies. The development of the two may alleviate the problem of supplying kerosene and gas to domestic users.

Creating short-term employment during the farming off-season period for farmers, so that minimal amount of income to buy food and the successive season farm inputs will help to discourage farmers from charcoal production. Already, the profit margin is low and the enterprise is labour intensive. Subsidising the farm input can help in solving the problem of deforestation for traditional fuels. When farm inputs are adequately subsidised by the government, the farmers can easily buy their farm input without recourse to any labour-intensive enterprise as charcoal.

Also instead of taxing charcoal at source, and by the forest department, it should be taxed at the point of sale and by the local government council through the local planning authorities. This would facilitate the reforestation programme.

Apart from educating and enlightening the communities on the importance of forest resources and conservation of same, greater community participation in forest management is vital. Forestry plantation project would assist in reversing the present declining Nigeria's forests through its expansion. People in the rural communities should be encouraged on reforestation and afforestation with species yielding fruit, gum and other crops that are of economic value to the communities.

There should be laws that guard against the cutting down of trees for charcoal in both private and public forest areas without planting others as replacement. But legislation alone cannot protect our forests without religiously enforcing them. It is a lot easier to disseminate charcoal in large scale than fossil fuels, because there is a well-developed market and there is no need for expensive infrastructure like refineries and processing. So, even though fossil fuels are in fact better for health and better for climate, they are more expensive and a lot harder to get out. There should be an appropriate policy that delivers gas and kerosene to end users for domestic use at affordable prices, which is possible with strong political will.

Finally, Nigeria has the financial and human resources to pipe gas into homes for domestic use. The problem in Nigeria is that most residential areas in Nigeria (both rural and urban settlements) are not well planned and this makes piping of gas into residential houses for domestic use difficult both in the rural and urban areas. To this, therefore, concerted efforts of government at all levels in Nigeria are required towards national physical development planning, state planning and local planning programmes which are useful components of National Development Planning (Adedipe,2007). 


\section{References}

Adeniyi A. (1995). Charcoal Production in Delta State. Kahney Books, Asaba Pp. 8 and 9.

Adedipe, B.O. (2007). First Foundation of Regional Planning. IBDL Education Publishers, Ilaro, Ogun State, Nigeria Pp. 22 \& 23.

Ajadi, K.O. (2004). Infrastructure provision for poverty alleviation in rural Nigeria: A case of Ifedapo region in Oyo State of Nigeria. The Environscope. Vol.1No 1 p. 58.

Development (2009). Africa in a new light: Investing in alternatives to kerosene and candles for Africans without electric lights. Developments, Issue 46, 2009 P.15 www.lightingafrica.org.

Encyclopedia of the Nations (2009). Nigeria Forestry. Encyclopedia of the Nations.

www.nationsencyclopedia.com.

FAO, (1993). Cited in Mohamed Abdullahi Elmi (June 2001) "Somalia's Degrading

Environmental"

http://www.apd-

somaliland.org/docs/

FAO (2005). State of the World's Forests' Report.

United Nations Food and Agriculture

Organization

Hao WM and Liu MH (1994). Spatial and temporal distribution of tropical biomass burning.

Global Biogeochemical Cycles 8, 495 - 503

GNU (2005) History of charcoal. www.en.wikipedia.org/wiki/charcoal.

Kammen O. and Lew (1995). Charcoal production and use technologies. www.kam.org/charcoal.

Kituyi E, Wandiga SO, Andreae MO and Helas G (2005). Biomass burning in Africa: Role in atmospheric change and opportunities for emission mitigation. In Climate Change and Africa (ed. Pak Sum Low) pp 79 - 89. Cambridge University Press.

LivingCountryside (2010). The history of charcoal -Worldwide farming and the countryside-

What's going on and why? LivingCountryside. www.charity-commission.gov.uk

Lyimo Karl (2009). Tanzania: If Charcoal Trade is This Lucrative, Let's Do it. www.allafrica.com September.

Ministry of Pastoral Development \& Environment (2004). Case Study. Impact of Charcoal Production on both the Environment and the Socio-economy of Pastoral Communities in Somaliland. Final Draft. Hargeisa

Ezzati,Majid Robert Bailis and Daniel Kammen (2005). Efficient charcoal production in Africa can save millions of lives. The Journal Science. Harvard School of Public Health, [RxPG] April 1. Supported by the United States Environmental Protection Agency Office of Atmospheric Programs, the Energy Foundation, the University of California Class of 1935 Chair, and the National Institute on Aging. http://www.hsph.harvard.edu/

MPD\&E (2004). "Impact of Charcoal Production on Environment and on the Socio Economy

of Pastoral Communities of Somaliland." University Duisburg-Essen, Germany.

Marufu TM (1999). Photochemistry of the African Troposphere: The influence of Biomass

Burning. PhD Thesis, University of Utrecht.

Menne, B. and R. Bertollini, (2000). 'The Health Impacts of Desertification and Drought', WHO in United Nations Convention to Combat Desertification in Those Countries Experiencing Serious Drought and/or Desertification, Particularly in Africa (UNCCD), Down to Earth: Newsletter of the UNCCD, No. 14, December.www.unep.org/ceh/endnotes/htm\#cho4 -01

Mitchell, Andrew (2009). "Big business to measure forest-footprint". Cited in Developments, Issue 46, 2009, www.developments.org.uk; www.forestdisclosure.com P.7.

Mohamed Abdullahi Elmi (June 2001). "Somalia's Degrading Environmental"

http://www.apd-somaliland.org/docs/

Olori Toye (2009). "Environment - Nigeria: Rich in oil dependent on firewood, IPS, Friday, $2^{\text {nd }}$ October. www.ipsnews.net/news,asp.

Popoola, T.M.,(2009). The role of charcoal production in the socio-economic development in Saki west local government. A terminal project submitted to the Department of Urban and Regional Planning, The Polytechnic of Ibadan, Nigeria.

Resch, Rensselear (2009). Charcoal production in the Democratic Republic of Congo. www.american./edu/TED/charcoal.htm.

www.charcoalenvironment.htm. September www.lucy.ukc.ac.uk/Rainforest/trefon/findings.ht $\mathrm{ml}$

Saki West Local Government (2008). Historical Background of Saki. Saki West Local

Government Publishers. 
Sertima , I.V.[1992] [ed]. Blacks in Science: Ancient and Modern, Transaction Books, New Brunswick.

Sexena, N.C. (1997). The woodfuel scenerio and policy issues in India. Centre for SustainableDevelopment LBS National Academy of Administration, Mussoorie.

Steiner Christoph et al (2003). Amazonian Dark Earths Living Countryside

http://geography.miningco.com/library/weekly/aa0 10598.htm

The Library of Congress Country Studies (2005). Back to Nigeria Economy, CIA World Fact Book $27^{\text {th }} \quad$ March. www.photius.com/countries/nigeria.

The Original Charcoal Company (2010). Story of Charcoal: Carrying on the environmental tradition: www.originalcharcoal.htm.
Twaynet (2008). Wood charcoal. www.twanet.com. October, 2009.

Udo, K. R.,(1987). The Human Geography of Tropical Africa. Heinemann Educational Books (Nigeria) LTd, Ibadan.

Wikipedia Foundation [2008].How to make charcoal. en .wikipedia.org.wiki/charcoal.

Working Woodland Trust (2008). A Brief History of Charcoal Making.

www.en.charcoalmaking.htm.

Wikipedia. Encyclopedia (2005). Charcoal production. www.en.wikipedia.org/wiki/charcoal. Wikipedia encyclopedia (2005). History of charcoal Production,

http//www.cornerpraie.org/historyonlinefuel.html. 